\title{
Political Economy: A Primer
}

\section{Matthew N. O. Sadiku, Yonghui Wang, Suxia Cui and Sarhan M. Musa}

\author{
Roy G. Perry College of Engineering \\ Prairie View A\&M University \\ Prairie View, TX 77446 \\ U.S.A
}

\begin{abstract}
Political economy is a branch of social science that studies the relationships between individuals and society and between markets and the state. Political economists study political ideology, economic structure, human nature, and moral philosophy. This paper provides a brief introduction to political economy.
\end{abstract}

Key Words: Political economy, Economics.

\section{INTRODUCTION}

Societies function and thrive on the basis of rules and laws. Society should broadly include nations, firms, social groups, or other organizations. The working of social rules is the central subject matter of political economy. Political economy is concerned with the political nature of decision making and how politics affects economic choices in a society. Political economy originated in moral philosophy in the 18 th century.

The tern "political economy" has undergone a range of meanings during its long lifetime. It is used as a synonym for economics or it may refer to different things. It may simply refer to the advice given by economists to the government on economic policy. Some regard it as a science of managing nations' resources in order to generate wealth. Most commonly, it refers to interdisciplinary studies drawing upon economics, sociology, philosophy, and political science.

Political economists are concerned with the allocation of scarce resources using politics within a state to provide for the people. The state is regarded as the institution that regulates the distribution of wealth and private property. In this regard, government is often described as responsible for peace, justice, and tolerable taxes. The production and distribution of wealth and power is studied as a whole in political economy.

\section{RELATED DISCIPLINES}

Political economy is a combination of politics, economics, sociology, philosophy, and history. The following studies use the term "political economy" with radically different perspectives [1]:

- Politics studies power relations and their relationship to achieving desired ends

- Philosophy rigorously studies a set of beliefs and their applicability to reality

- Economics studies the distribution of resources so that the material wants of a society are satisfied

- Sociology studies the effects of persons' involvement in society as members of groups and how that changes their ability to function

- Anthropology studies political economy by investigating regimes of political and economic value that condition tacit aspects of sociocultural 
- Psychology is the fulcrum on which political economy exerts its force in studying decision making

- History documents change and some historical works take political economy as the narrative's frame.

- Ecology deals with political economy because human activity has the greatest effect upon the environment

- Cultural studies examines social class, production, labor, race, gender, and sex.

\section{CONCEPT OF POLITICAL ECONOMY}

We identify four such foundational elements of political economy [2]: value, class, labor, and social control.

- Value: The creation of wealth: Value has to do with the production of wealth. Wealth creation is a constant requirement in our economy, and it isthe basis upon which all capitalist activity rests.

- Class: A persistent reality. Class has to do with lifestyle and taste or with social status. Although class structure in current capitalist societies is different from that of previous centuries, classes have not disappeared.

- Labor: Rewarded and unrewarded. Capitalism depends on wage labor to create wealth.. The meagerly rewarded contribution of humans to many computational systems is an increasingly common labor relation. The economic value generated is not equitably distributed. It often favors a select group of actors at the expense of others.

- Social control: Commitment and coercion. All societies ensure that people behave according to rules and expectations. Although technologies such as the Internet are used for emancipatory purposes, they have also turned into instruments of surveillance, control, and coercion. mechanisms

Although the intellectual terrain of political economy is vast, the study of political economy can be split into two sections: Classical Political Economy and Modern Political Economy.

\section{MODERN POLITICAL ECONOMY}

Classical political economy in the 17th and 18th centuries understood economic activity as being mutually generated by social, cultural, and historical forces. Modern political economy is the study and use of how economic theory to influence social and economic systems, such as capitalism, socialism and communism. It covers the following three ideologies [3]:

- Liberalism: Wealth comes the use of land and other natural resources, along with capital in the form of durable goods and labor. Everyone can benefit from economics, which is not a zero sum game. Since there is equality of opportunity, everyone can win, when the conditions are fair and favorable. Political economists like Malthus, Hegel, and Marx critiqued capitalism in their works as they presented alternatives to liberalism. Since liberals (such as Locke) generally believe that individuals are virtuous, they can govern themselves with as little government intervention as possible. They believe that the state which governs least is the one which governs best.

- Marxism: Marxism is a political economic system based on the core idea that wealth and private property can be dangerous for individuals. It exclusively uses the concepts of ruling class and dominant class. Labor power is seen as the real source of wealth. Wealth comes from manual labor and exchange and all individuals should benefit from economics. Economics is regarded to be a zero sum game. (A zero sum game is a term for the idea that when one individual gains wealth, another individual must lose that same amount since wealth cannot be created or destroyed). Profit in capitalism comes from surplus labor extracted from the worker. The private ownership of the means of production will inherently breed inequality and leave some in society with immense wealth while others are in poverty.

- Economic Nationalism: Wealth comes from the use of power, and the use of power facilitates the accumulation of wealth. Individuals should work to benefit the wealth and power of the state. Economics is considered a zero sum game. The state's accumulation of public property is better for the society than the individual accumulation of private property is. Individuals are ignorant and confused, and cannot form a cohesive society without a strong state.

\section{INTERNATIONAL POLITICAL ECONOMY}

International political economy (IPE) (or global political economy) analyzes the link between economics and international relations. It is the study of how citizens relate to the state and how the states in the world relate to each other. It is mainly concerned with how political forces like states, individual actors, and institutions shape systems through global economic 
interactions. International political economy profits from the interdisciplinary approaches and concepts that originated in the study of politics, economics, sociology, philosophy, and history. IPE may require collaboration, i.e. cooperating to achieve common goals, working across boundaries in multi-sector relationships.

\section{APPLICATIONS OF POLITICAL ECONOMY}

Recent years have witnessed the steady growth of critical political economy approaches to tourism development [4]. Political economy is applied in immigration as a dynamic model in which individuals care about their children and recognize that immigration influences the current and future labor market [5]. Political economy in developing nations has profound influence on the growth and decay of mining towns, and the centrality of urban planning [6]. Education policymakers increasingly rely on research on how education policy should be made in order to improve students' educational performance. In the political economy of education policy, interactions between policymakers and public opinion can create some discrepancies [7]. The transition of political economy spurred by globalization and political reforms has taken its toll on families and gender roles. This has led to the destabilization of families [8].

Other applications include food labelling, understanding violence, managing teachers, housing, national security, and communication.

\section{CONCLUSION}

Political economy is fundamentally premised on the interaction of political and economic processes within a community. It involves the distribution of power and wealth between different groups and individuals. Political economy is a growing discipline as well as a moving target. For more information on political economy see the books in [9-15] and the following journals devoted to it:

- New Perspectives on Political Economy

- European Journal of Political Economy

- New Political Economy

- Journal of Political Economy

\section{REFERENCES}

[1] "Political economy," Wikipedia, the free encyclopedia https://en.wikipedia.org/wiki/Political_economy

[2] H. Ekbia and B. Nardi, "The political economy of computing: The elephant in the HCI room," Interactions, Nov. -Dec. 2015, pp. 46-49.

[3] "Political economy,"https://en.wikibooks.org/wiki/Political_Economy

[4] R. Bianch, "The political economy of tourism development: A critical review," Annals of Tourism Research, vol. 70, 2018, pp. 88-102.

[5] H. Born, A. R. Lopez-Velasco, "Intergenerational mobility and the political economy of immigration," Journal of Economic Dynamics \& Control, vol. 94, 2018, pp. 72-88.

[6] P. B. Cobbinah and C. Amoak, "From Gold Coast to Ghana: Changing political economy of mining towns," Cities, vol. 83, Dec. 2018, pp. 83-91.

[7] M. R. Busemeyera, P. Lergetporerb, and L. Woessmannc, "Public opinion and the political economy of educational reforms: A survey," European Journal of Political Economy, vol. 53, 2018, pp. 161-185.

[8] T. Hiroko, "The political economy of familial relations: The Japanese state and families in a changing political economy," Asian Journal of Political Science, vol. 16, no. 2, 2008, pp. 196-214.

[9] M. Staniland, What Is Political Economy? A Study of Social Theory and Underdevelopment. New Haven: Yale University Press, 1985.

[10] D. N. Balaam and B. Dillman, Introduction to International Political Economy. New York, NY : Routledge, $7^{\text {th }}$ edi., 2016.

[11] O. Lange, Political Economy. Elsevier, volume 2, 1971.

[12] D. Ricardo, Principles of Political Economy and Taxation. London: George Bell and Sons, 1891.

[13] H. S. Jevons, The Theory of Political Economy. New York, NY: Sentry Press, $5^{\text {th }}$ ed., 1965. 
[14] N. Schofield, G. Caballero, and D. Kselman (eds.), Advances in Political Economy: Institutions, Modelling and Empirical Analysis. Springer, 2013.

[15] N. Capaldi and G. Lloyd (eds.), The Two Narratives of Political Economy. Co-published by John Wiley \& Sons, Inc. Hoboken, NJ and Scrivener Publishing, Salem, MA, 2011.

\section{About the Authors}

Matthew N.O. Sadiku is a professor in the Department of Electrical and Computer Engineering at Prairie View A\&M University, Prairie View, Texas. He is the author of several books and papers. His areas of research interest include computational electromagnetics and computer networks. He is a fellow of IEEE.

Yonghui Wang is currently an assistant professor with the Department of Computer Science, Prairie View A\&M University, Prairie View, TX. His research interests include digital signal processing, image and video coding, and wavelets.

Suxia Cui is an associate professor of Electrical and Computer Engineering Department at Prairie View A\&M University. She has published journal and conference articles in the field of wavelets, image processing, and video coding. Her research interests include data compression, signal classification, image and video processing.

Sarhan M. Musa is a professor in the Department of Engineering Technology at Prairie View A\&M University, Texas. He has been the director of Prairie View Networking Academy, Texas, since 2004. He is an LTD Sprint and Boeing Welliver Fellow 